\title{
Ekoturizam specijalnog rezervata prirode „Deliblatska peščara“ u uslovima pandemije COVID-19
}

\section{Ecotourism of the special nature reserve "Deliblatska peščara" in the conditions of the COVID-19 pandemic}

\author{
Snežana Štetić1* ${ }^{*}$ Igor Trišić ${ }^{2}$, Igor Gvozden ${ }^{3}$ \\ 1,2Balkanska mreža turističkih stručnjaka, Beograd, Srbija \\ Balkan Network of Tourism Experts, Belgrade, Serbia \\ ${ }^{3}$ Ugostiteljsko-turistička škola, Beograd, Srbija \\ School for restaurant and tourism business, Belgrade, Serbia \\ *Autor za prepisku / Corresponding author
}

Rad primljen / Received: 09.12.2020, Rad prihvaćen / Accepted: 07.05.2021.

\begin{abstract}
Sažetak: Potencijalno značajni faktori razvoja ekoturizma u Specijalnom rezervatu prirode „Deliblatska peščara“ jesu: endemična flora i fauna, raznovrstan ekosistem, postojanje ramsarskih staništa, postojanje zakonske legislative koja reguliše zaštitu, bogata socio-kulturna baština lokalnog stanovništva, postojanje zona zaštite unutar područja i drugi faktori. Deliblatska peščara karakteriše vrlo redak dinski reljef, koji je svojstven samo ovom zaštićenom području. Pesak koji je ovde u značajnoj meri sastojak tla, uticao je na razvoj posebne flore i faune, od kojih su pojedine vrste endemiti i ne mogu se pronaći u drugim zaštićenim područjima. Pored prirodnih vrlo značajni faktori za razvoj ekoturizma jesu društvene vrednosti. Na prostoru rezervata postoje brojna naselja koja raspolažu značajnim kulturnim, spomeničkim i arheološkim nasleđem. Cilj istraživanja je da se uz pomoć kvantitativne metodologije utvrdi da li su i u kojoj meri uslovi pandemije uticali na potrebe turista za ekoturizmom i putovanjima u prirodu. Rezultati istraživanja ispitivanja turista koji su posetili ovo zaštićeno prirodno područje, ukazuju na značajni uticaj pandemije uslovljene COVID-19 na razvoj ekoturizma u Specijalnom rezervatu prirode "Deliblatska peščara“. Ključne reči: ekoturizam, Deliblatska peščara, endemska flora i fauna, pandemija COVID-19.
\end{abstract}

\begin{abstract}
As potentially significant factors of ecotourism development of the Special Nature Reserve "Deliblatska Peščara" are endemic flora and fauna, diverse ecosystem, Ramsar habitats, legal legislation regulating protection, the rich socio-cultural heritage of the local community, the existence of protection zones within the area and other factors. Deliblato sands are characterized by a very rare dune relief, which is characteristic only for this protected area. Sand, which is a significant component of the soil here, has influenced the development of special flora and fauna, some of which are endemic and cannot be found in other protected natural areas. In addition to natural, very important factors for the development of ecotourism are socio-cultural values. There are numerous settlements in the reserve that have a significant cultural, monumental and archaeological heritage. The research aims is to determine, with the help of quantitative methodology, whether and to what extent the conditions of the pandemic have affected the needs of tourists for ecotourism and nature trips. The results of the research by examining tourists who visited this protected natural area, indicate a significant impact of the pandemic caused by COVID-19 on the ecotourism development of Special Nature Reserve "Deliblatska Peščara".
\end{abstract}

Keywords: ecotourism, Deliblato sands, endemic flora and fauna, Covid-19 pandemic.

\footnotetext{
${ }^{1}$ orcid.org/0000-0002-1137-4441, e-mail: stetic.snezana@gmail.com

2orcid.org/0000-0002-6497-9276, e-mail: trisici@hotmail.com.
} 


\section{UVOD / INTRODUCTION}

Specijalni rezervat prirode „Deliblatska peščara“ je zaštićeno prirodno područje u jugoistočnom delu Vojvodine, kojeg čini specifični ekosistem sa vrlo različitim prirodnim faktorima (Simić \& Puzović, 2008; Brankov, 2010; Trišić, 2019; Izveštaj o sprovođenju programa zaštite prirodnih dobara za 2019. godinu, 2020). Ovaj rezervat karakteriše vrlo redak dinski reljef, koji je svojstven samo ovom zaštićenom području. Pesak koji je ovde u značajnoj meri sastojak tla, uticao je na razvoj posebne flore i faune, od kojih su pojedine vrste endemiti i ne mogu se pronaći u drugim zaštićenim područjima Vojvodine (Izveštaj o sprovođenju programa zaštite prirodnih dobara za 2019. godinu, 2020). Takvi su banatski božur (Paeonia officinalis L.), pančićev pelen (Artemisia pancicii (Janka) Ronniger), šerpet (Rindera umbellata Bunge), bademić (Prunus tenella Batsch), peščarsko smilje (Helichrysum arenarium) i kleka (Juniperus communis) koja je i jedini samonikli četinar Panonske nizije. Pored flore značajni su i brojni predstavnici faune (Puzović et al., 2015; Program zaštite životne sredine Autonomne Pokrajine Vojvodine za period 2016-2025. godine („SI. list AP Vojvodine“, 10/2016); Amidžić et al., 2017). SRP „Deliblatska peščara“ jedinstvenim zaštićenim područjem čine i 6 staza zdravlja, predviđenih za korisnike sportsko-rekreativnog turizma, edukativnog, eko i zdravstvenog turizma. Ukupna dužina staza je oko 50 km (Trišić, 2019).

Pored navedenih faktora na području rezervata nalazi se čuveno lovište „Deliblatska peščara“ ukupne površine 31.036,55 ha (Plan upravljanja za Specijalni rezervat prirode „Deliblatska peščara“ 20112020, 2011). Na prostoru rezervata postoje kapaciteti koji omogućavaju razvoj ekoturizma, izletničkog, ruralnog, nautičkog, vinskog, sportskog, lovnog i edukativnog turizma (Brankov, 2010; Puzović et al., 2015). To omogućavaju smeštajni kapaciteti Školskorekreativnog centra „Čardak“ (130 ležaja) i lovačke kuće, kampovi i kapaciteti seoskih domaćinstava u Šumarku, Dubovcu, Deliblatu, Skorenovcu i Kovinu (Plan upravljanja za Specijalni rezervat prirode „Deliblatska peščara“ 2011-2020, 2011; Pravilnik o unutrašnjem redu i čuvarskoj službi Specijalnog rezervata prirode „Deliblatska peščara“ („Službeni glasnik RS", 10/2016)). Kao poslednja i najveća geografska oblast peščarsko-stepske, šumske i močvarne vegetacije koja je nekada dominirala Panonskom nizijom, SRP „Deliblatska peščara” je jedan od najvažnijih centara biodiverziteta u Srbiji (Pavlović et al., 2017; Trišić \& Štetić, 2020). Svi navedeni faktori doprinose razvoju ekoturizma kao značajnog oblika turizma u ovom specijalnom rezervatu prirode (Kovačev et al., 2014; Štetić \& Šimičević, 2018).
Specijalni rezervat prirode „Deliblatska peščara“ ima povoljan geografski položaj i dobru saobraćajnu povezanost sa svim gradovima u zemlji i u regionu (Trišić, 2019). Položaj ovog rezervata može se sagledati na Slici 1.

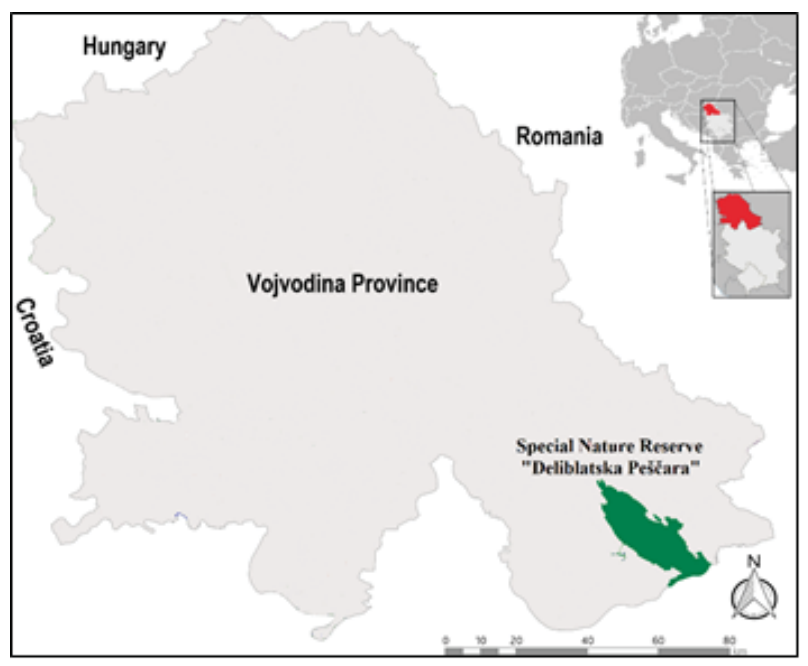

Slika 1 - Mapa specijalnog rezervata prirode „Deliblatska Peščara“

Figure 1 - Map of Special Nature Reserve "Deliblatska Peščara" Izvor / Source: Trišić (2019)

Pandemija COVID-19 u Republici Srbiji proglašena je u martu 2020. godine. Svoj negativan uticaj ostvarila je na čitavo čovečanstvo. Pored toga što je virus smrtonosan, ostavio je značajne posledice na život ljudi, ekonomiju, privredu i način života. Poseban uticaj odrazio se na turizam i zabranu putovanja. $U$ vreme socijalne distance i zabrane javnih okupljanja, ljudi su se intenzivno okrenuli ka prirodi. Vreme za odmor upravo su težili da provedu u prirodi. Kako je turizam u vreme pandemije moguć u vrlo kontrolisanim i ograničenim prirodnim uslovima posebnih prostornih celina, autori su za područje istraživanja nevedenog uticaja izabrali Specijalni rezervat prirode „Deliblatska peščara“.

Cilj istraživanja u ovom radu jeste da se ispita u kojoj meri je pandemija COVID-19 uticala na odluke turista o putovanju i razvoj ekoturizma u zaštićenom prirodnom području. Autori su uz pomoć kvantitativne metodologije analizirali odgovore 150 turista koji su posetili ovo zaštićeno područje. Rezultati istraživanja mogu doprineti konstituisanju stavova o razvoju turizma baziranog na prirodi u uslovima pandemije i mogu pomoći u planiranju turizma i njegovom razvoju u zaštićenim prirodnim područjima, gde su prirodni faktori primarni motiv $u$ donošenju odluke o putovanju. 


\section{MATERIJALI I METODE /} MATERIALS AND METHODS

U zaštićenom prirodnom području „Deliblatska peščara" mogu se razvijati različiti specifični oblici turizma bazirani na prirodi. Kako je ovo osetljiva turistička destinacija primarni oblik turizma je ekoturizam (Štetić et al., 2019). Ovaj oblik turizma ima za cilj promociju prirodnih karakteristika područja u kojem se realizuje i kao najvažnije, ekoturizam unapređuje kvalitet prirode, utiče na sisteme zaštite prostora i doprinosi sveukupne benefite za zaštićeno područje (Milićević et al., 2021), turiste i lokalno stanovništvo (McCool et al., 2001; Twining-Ward \& Butler, 2002; Buckley, 2003; Cottrell et al., 2013). Ekoturizam može imati pozitivan uticaj na razvoj održivog turizma, doprinoseći ekološkoj, ekonomskoj i socio-kulturnoj održivosti (Queiroz et al., 2014; Sowinska-Świerkosz \& Chmielewski, 2014; Scholtz et al., 2015; Banos-Gonzales et al., 2016; Lee \& Hsieh, 2016; Agyeiwaah et al., 2017; Vučetić, 2018; Asmelash \& Kumar, 2019).

Stavovi turista o određenim pojavama mogu biti od značaja za definisanje trenutnog stanja turizma. Turisti mogu ukazati na uticaje različitih faktora na njihove aktivnosti u turističkim destinacijama (Trišić et al., 2020). Uz pomoć kvantitativne metodologije u radu su analizirani podaci dobijeni anketiranjem turista koji su posetili Specijani rezervat prirode "Deliblatska peščara“. Ispitivan je uticaj pandemije COVID-19 na razvoj turizma ove destinacije, odnosno razvoj ekoturizma u zaštićenom prirodnom području u uslovima pandemije. Anketni upitnik između ostalog sadrži 4 pitanja u formi tvdnji koje se odnose na uticaj COVID-19 na odluke o putovanjima. Ispitivanje je vršeno uz poštovanje svih mera zaštite od infekcije (nošenje zaštitnih maski i rukavica, održavanje socijalne distance i poštovanje mera o dozvoljenom broju ljudi). Ispitanici su svoje odgovore rangirali na petostepenoj Likertovoj skali, pri čemu skala 1 označava neslaganje u potpunosti, skala 3 neutralan stav i skala 5 označava slaganje u potpunosti (Maple et al., 2010; Puhakka \& Siikamäki, 2012; Scholtz et al., 2012; Dolnicar \& Grün, 2013; Kruger et al., 2013; Rasoolimanesh \& Jaafar, 2016). Pitanja u formi tvrdnji koja su postavljena ispitanicima mogu se sagledati u Tabeli 1.

Tabela 1 - Model upitnika Table 1 - Model of Questionnaire

\begin{tabular}{|l|l|}
\hline $\mathrm{n}_{1}$ & $\begin{array}{l}\text { Preferiram turizam baziran na prirodi } \\
\text { I prefer nature-based tourism }\end{array}$ \\
\hline $\mathrm{n}_{2}$ & $\begin{array}{l}\text { Pandemija COVID-19 je uticala da posetim } \\
\text { zaštićeno prirodno područje } \\
\text { The COVID-19 pandemic affected my visit to a } \\
\text { protected natural area }\end{array}$ \\
\hline $\mathrm{n}_{3}$ & $\begin{array}{l}\text { Posetio bih ovo područje i da nema uticaja } \\
\text { pandemije COVID-19 } \\
\text { I would visit this area even if there was no } \\
\text { impact of the COVID-19 pandemic }\end{array}$ \\
\hline $\mathrm{n}_{4}$ & $\begin{array}{l}\text { Posetiću ovo zaštićeno prirodno područje i } \\
\text { nakon pandemije COVID-19 } \\
\text { I will visit this protected natural area even after } \\
\text { the COVID-19 pandemic }\end{array}$ \\
\hline
\end{tabular}

Dobijeni podaci nakon sprovedenog upitnika analizirani su uz pomoć deskriptivne statistike i prikazani uz pomoć grafikona i tabela.

\section{REZULTATI I DISKUSIJA / RESULTS AND DISCUSSION}

Ispitinacima su pitanja iz upitnika postavljana na terenu u toku posete zaštićenog područja i korišćenjem elektronske forme upitnika uz pomoć društvenih mreža koje promovišu turizam Deliblatske peščare. Ispitivanje je obavljeno u toku 2020. i 2021. godine. Ukupno je anketirano 150 turista. Svi upitnici su validni. Svi anketirani turisti imaju više od 18 godina. Gradovi iz kojih su turisti jesu: Beograd, Kovin, Vršac, Pančevo, Novi Sad i Smederevo. Struktura ispitanika može se sagledati u Tabeli 2.

Tabela 2 - Struktura ispitanika / Table 2 - Structure of respondents

\begin{tabular}{|l|c|c|}
\hline Pol / Gender & N & Percent / Procenata (\%) \\
\hline Muškarci / Male & 65 & 43.33 \\
\hline Žene / Female & 85 & 56.67 \\
\hline Ukupno / Total & 150 & 100.0 \\
\hline Obrazovanje / Education & $\mathbf{N}$ & Percent / Procenata (\%) \\
\hline Osnovno obrazovanje / Primary education & 105 & \multicolumn{2}{|c|}{70} \\
\hline Srednje obrazovanje / Secondary education & 31 & 20.66 \\
\hline Više obrazovanje / Higher education & 14 & \multicolumn{2}{|c|}{100} \\
\hline Visoko obrazovanje / High education & 150 & Min \\
\hline Ukupno / Total & $\mathbf{N}$ & Max \\
\hline \multirow{2}{*}{ Starosna struktura / Age structure } & 150 & \multicolumn{2}{|c|}{ Std. Dev. } \\
\cline { 2 - 4 } & Srednja vr. / Mean & 14.228 \\
\cline { 2 - 4 }
\end{tabular}

Izvor: proračun autora / Source: author's calculation 
Od ukupnog broja ispitanika $56,67 \%$ jesu žene. Osnovno obrazovanje nema nijedan ispitanik, dok najviše ispitanika ima srednje obrazovanje (70\%). Više obrazovanje ima $20,66 \%$, dok $9,34 \%$ ispitanika ima visoko obrazovanje. Ovakva obrazovna i starosna struktura omogućava pouzdanost odgovora ispitanika na postavljena pitanju u upitniku.

Na tvrdnju ( $\left.\mathrm{n}_{1}\right)$ - Preferiram turizam baziran na prirodi, ispitanici su svoje odgovore iskazali na sledeći način (Tabela 3, Grafikon 1):

Tabela 3 / Table 3

\begin{tabular}{|c|c|c|c|}
\hline \multicolumn{2}{|c|}{} & $\mathrm{N}$ & $\%$ \\
\hline \multirow{4}{*}{$\mathrm{n}_{1}$} & 1 & $/$ & $/$ \\
\cline { 2 - 4 } & 2 & 14 & 9.33 \\
\cline { 2 - 4 } & 3 & 11 & 7.33 \\
\cline { 2 - 4 } & 4 & 24 & 16 \\
\cline { 2 - 4 } & 5 & 101 & 67.34 \\
\cline { 2 - 4 } & Total & 150 & 100,0 \\
\hline
\end{tabular}

Izvor: Proračun autora / Source: author's calculation

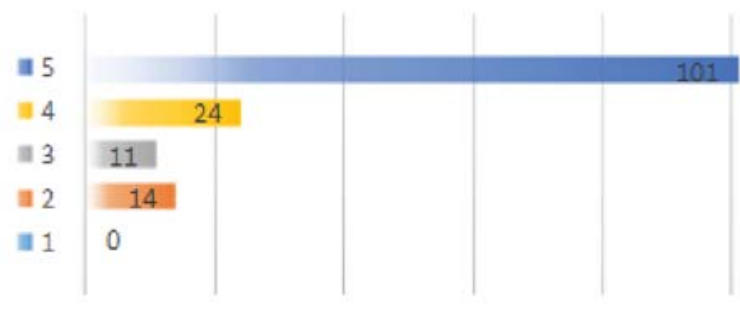

Grafikon 1 / Graph 1

Legenda: 5 - Potpuno se slažem; 4 - Delimično se slažem; 3 - Niti se slažem, niti se ne slažem; 2 Delimično se ne slažem; 1 - Potpuno se ne slažem.

Note: 5 - I absolutely agree; 4 - I partially agree; 3 neither agree nor disagree; 2 - I partially disagree; 1 - I absolutely disagre

Analizom podataka u Tabeli 3 i Grafikonu 1, možemo zaključiti da se značajan broj ispitanika izjasnio u potpunosti $(67,34 \%)$ i delimično $(16 \%)$ da preferira turizam baziran na prirodi. Ovo potvrđuje činjenicu da su na odluku turista da posete zaštićeno područje uticali upravo prirodni atributi koji omogućavaju razvoj turizma baziranog na prirodi (Weaver, 2010; Dudley et al., 2014; Navarro et al., 2020). Ukupno $7,33 \%$ ispitanika ima neutralan stav po ovom pitanju, dok $9,33 \%$ ispitanika ne preferira ekoturizam.

Na tvrdnju $\left(\mathrm{n}_{2}\right)$ - Pandemija COVID-19 je uticala da posetim zaštićeno prirodno područje, ispitanici su se izjasnili na sledeći način (Tabela 4,Grafikon 2):
Tabela 4 / Table 4

\begin{tabular}{|c|c|c|c|}
\hline \multicolumn{2}{|c|}{} & N & $\%$ \\
\hline \multirow{4}{*}{$\mathrm{n}_{2}$} & 1 & $/$ & $/$ \\
\cline { 2 - 4 } & 2 & $/$ & $/$ \\
\cline { 2 - 4 } & 3 & $/$ & $/$ \\
\cline { 2 - 4 } & 4 & 19 & 12.66 \\
\cline { 2 - 4 } & 5 & 131 & 87.34 \\
\cline { 2 - 4 } & Total & 150 & 100.0 \\
\hline
\end{tabular}

Izvor: Proračun autora / Source: author's calculation

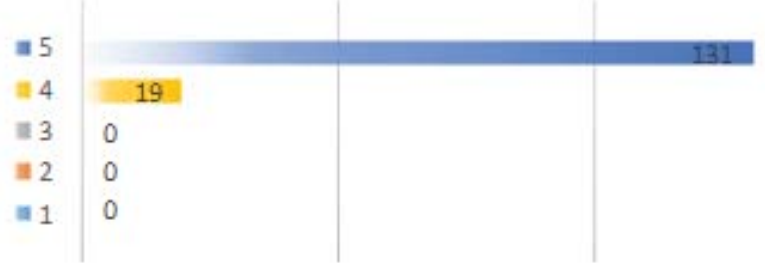

Grafikon 2 / Graph 2

Legenda: 5 - Potpuno se slažem; 4 - Delimično se slažem; 3 - Niti se slažem, niti se ne slažem; 2 Delimično se ne slažem; 1 - Potpuno se ne slažem.

Note: 5 - I absolutely agree; 4 - I partially agree; 3 neither agree nor disagree; 2 - I partially disagree; 1 - I absolutely disagre

Analizom podataka u Tabeli 4 i Grafikonu 2, možemo zaključiti da se značajan broj ispitanika izjasnio u potpunosti $(87,34 \%)$ i delimično $(12,66 \%)$, da je pandemija COVID-19 uticala na njihovu odluku da posete Specijalni rezervat prirode „Deliblatska peščara". Neutralan i negativan stav prema ovoj tvrdnji nije iskazao nijedan ispitanik. Analizm odgovora na postavljeno drugo pitanje zaključuje se da je pandemija COVID-19 bila od presudnog značaja za donošenje odluke da se poseti Speciajni rezervat prirode „Deliblatska pešačara“. To predstavlja i realizaciju osnovnog cilja ovog istraživanja.

Na tvrdnju $\left(\mathrm{n}_{3}\right)$ - Posetio bih ovo područje i da nema uticaja pandemije COVID-19, ispitanici su se izjasnili na sledeći način (Tabela 5 , Grafikon 3):

Tabela 5 / Table 5

\begin{tabular}{|c|c|c|c|}
\hline \multicolumn{2}{|c|}{} & $N$ & $\%$ \\
\hline \multirow{4}{*}{$N_{3}$} & 1 & 16 & 10.67 \\
\cline { 2 - 4 } & 2 & 18 & 12 \\
\cline { 2 - 4 } & 3 & 10 & 6.67 \\
\cline { 2 - 4 } & 4 & 36 & 24 \\
\cline { 2 - 4 } & 5 & 70 & 46.66 \\
\cline { 2 - 4 } & Total & 150 & 100,0 \\
\hline
\end{tabular}

Izvor: Proračun autora / Source: author's calculation 


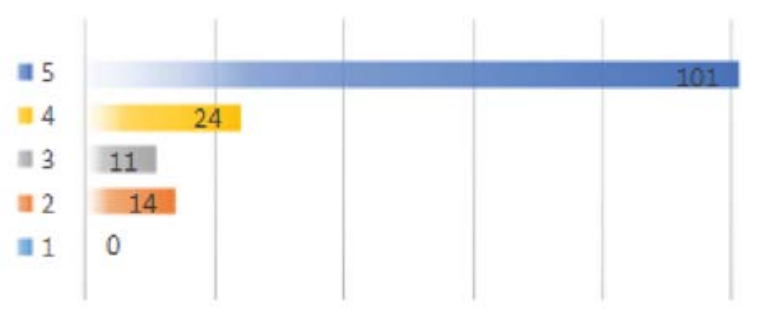

Grafikon 3 / Graph 3

Legenda: 5 - Potpuno se slažem; 4 - Delimično se slažem; 3 - Niti se slažem, niti se ne slažem; 2 Delimično se ne slažem; 1 - Potpuno se ne slažem.

Note: 5 - I absolutely agree; 4 - I partially agree; 3 neither agree nor disagree; 2 - I partially disagree; 1 - I absolutely disagre

Analizom odgovora u Tabeli 5 i Grafikonu 3, zapaža se da bi 106 ispitanika (70,66\%) posetili ovo zaštićeno prirodno područje i da nije pandemije COVID-19. Ukupno $6,67 \%$ ispitanika ima neutralan stav po ovom pitanju, dok 34 ispitanika $(22,67 \%)$ ne bi posetili ovo zaštićeno prirodno područje da nije pandemije.

Rezultati dobijeni nakon analize odgovora na pitanje u vezi s trećom tvrdnjom ukazuju na činjenicu da je 34 ispitanika posetilo ovo područje zbog nemogućnosti putovanja u druge destinacije, zbog epidemiološke situacije.

Na tvrdnju $\left(\mathrm{n}_{4}\right)$ - Posetiću ovo zaštićeno prirodno područje i nakon pandemije COVID-19, ispitanici su se izjasnili na sledeći način (Tabela 6, Grafikon 4):

Tabela 6 / Table 6

\begin{tabular}{|c|c|c|c|}
\hline \multicolumn{2}{|c|}{} & N & $\%$ \\
\hline \multirow{4}{*}{$\mathrm{n}_{1}$} & 1 & $/$ & $/$ \\
\cline { 2 - 4 } & 2 & $/$ & $/$ \\
\cline { 2 - 4 } & 3 & $/$ & $/$ \\
\cline { 2 - 4 } & 4 & 15 & 10 \\
\cline { 2 - 4 } & 5 & 135 & 90 \\
\cline { 2 - 4 } & Total & 150 & 100,0 \\
\hline
\end{tabular}

Izvor: Proračun autora / Source: author's calculation

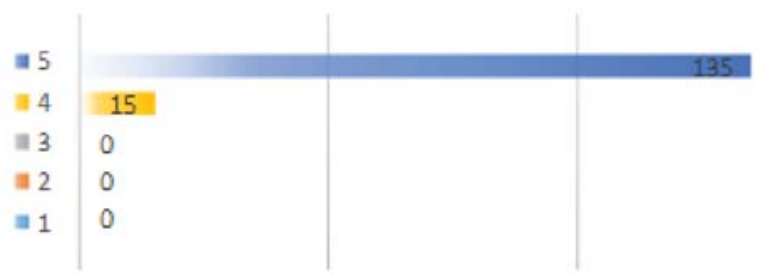

Grafikon 4 / Graph 4
Legenda: 5 - Potpuno se slažem; 4 - Delimično se slažem; 3 - Niti se slažem, niti se ne slažem; 2 Delimično se ne slažem; 1 - Potpuno se ne slažem.

Note: 5 - I absolutely agree; 4 - I partially agree; 3 neither agree nor disagree; 2 - I partially disagree; 1 - I absolutely disagre

Analizom odgovora u Tabeli 6 i Grafikonu 4, zaključuje se da će 135 ispitanika (90\%) sigurno posetiti ovo područje i nakon pandemije, dok će $10 \%$ ispitanika verovatno posetiti ovo zaštićeno prirodno područje. Neutralan i negativan odgovor nije dao nijedan ispitanik.

Dobijeni podaci ukazuju da su turisti posetom zaštićenog prirodnog područja, u uslovima loše epidemiološke situacije i zabrane realizacije mnogih drugih turističkih kretanja, stekli određenu naviku da posećuju ovakve turističke destinacije nakon normalizacije zdravstvene situacije i uslova putovanja..

\section{ZAKLJUČAK / CONCLUSION}

Ekoturizam je oblik turizma utemeljen na prirodnim faktorima koji ima za cilj razvoj ekološke svesti kod turista, zaštitu prirode i unapređenje njenih elemenata. Koristi od ovog oblika turizma bi trebalo da imaju priroda, turisti, upravljači destinacijom, lokalno stanovništvo i ekonomija. Ovaj specifičan oblik turizma vezuje se za osetljive turističke destinacije. Zbog posedovanja izuzetnih prirodnih vrednosti Speciajlni rezervat prirode „Deliblatska peščara“ predstavlja destinaciju ekoturizma ili drugih specifičnih oblika turizma baziranih na prirodi. Kako poseduje povoljan geografski položaj i dobru saobraćajnu povezanost sa svim većim gardskim centrima u zemlji i u regionu, ovaj rezervat prirode može biti eko-destinacija domaćih i međunarodnih turista.

U uslovima pandemije COVID-19, kada su putovanja u strane zemlje onemogućena, stanovništvo ima značajnu potrebu za putovanjem u prirodne turističke destinacije. Takve su zaštićena prirodna područja, parkovi prirode, izletišta, ruralni predeli i manje naseljene prostorne celine. Putovanja u zaštićena prirodna područja u uslovima pandemije su intezivirana. Razlog je potreba stanovništava za odlaskom iz gradskih sredina. U zaštićenim prirodnim područjima uz poštovanje svih zdravstvenih mera zaštite, turisti realizuju svoju potrebu za izletničkim, rekreativnim, sportskim, edukativnim, ribolovnim i drugim oblicima turizma, među kojima značajno mesto zauzima i ekoturizam kao noviji vid turizma baziran na prirodi. Pored navedenih oblika turizma, turisti u sklopu posete zaštićenim područjima prisustvuju i različitim manifestacijama, pa se komplementarnost ovih oblika turizma ogleda u pozitivnim sociokulturnim uticajima. 
Nakon sprovedenog istraživanja uticaja pandemije COVID-19 na razvoj ekoturizma, može se zaključiti da su turisti kao razlog posete Specijalnog rezervata prirode „Deliblatska peščara“ u velikom procentu naveli lošu epidemiološku situaciju. Veliki broj ispitanika je iznelo da je u potpunosti $(87,34 \%)$ ili delimično (12,66\%), pandemija COVID-19 uticala na njihovu odluku da posete Specijalni rezervat prirode „Deliblatska peščara“. Ukupno $22,67 \%$ turista ne bi posetilo ovo zaštićeno područje da nije došlo do uslova pandemije. Ovaj podatak ukazuje na činjenicu da loša epidemiološka situacija ima uticaj na razvoj ekoturizma ili drugih oblika turizma utemeljenih na prirodi. Ovo predstavlja i osnovni cilj ovog istraživanja. Značajan podatak nakon sprovedenog istraživanja jeste da će svi ispitani turisti posećivati ovo područje i nakon normalizacije epidemiološke situacije.

Ograničenja $\mathrm{u}$ istraživanju bila su poštovanje mera zaštite protiv zaraznih bolesti koje je propisala Vlada Republike Srbije, zbog kojih brojni turisti nisu želeli da budu anketirani, da se ne bi izlagali mogućoj infekciji u toku kontakta u procesu anketiranja. Pretpostavke su da bi kod većeg uzorka ovi rezultati bili još izraženiji.

Dobijeni rezultati istraživanja mogu poslužiti u izradi strategija razvoja turizma u sklopu planiranja određenih specifičnih oblika turizma u destinacijama sa osetljivim ekosistemom, kakva su upravo zaštićena prirodna područja. Kako će uticaj pandemije ostati duži vremenski period i kako su se turističke navike modifikovale i prilagodile ovim nepovoljnim uslovima, ekoturizam može predstavljati značajan oblik turističkih kretanja kako u našoj tako i u zemljama širom sveta.

\section{LITERATURA / REFERENCES}

[1] Agyeiwaah, E., McKercher, B., \& Suntikul, W. (2017). Identifying core indicators of sustainable tourism: A path forward? Tourism Management Perspectives, 24, 26-33. https://doi.org/10.1016/j.tmp.2017.07.005

[2] Amidžić, L., Krasulja, S., \& Belij, S. (2017). Zaštićena prirodna dobra Srbije. Beograd: Ministarstvo zaštite životne sredine, Zavod za zaštitu prirode Srbije.

[3] Asmelash, A.G., \& Kumar, S. (2019). The structural relationship between tourist satisfaction and sustainable heritage tourism development in Tigrai, Ethiopia. Heliyon, 5(3), E01335. https://doi.org/10.1016/j.heliyon.2019.e01335

[4] Banos-Gonzales, I., Martinez-Fernandez, J., \& Esteve-.Selma, M.A. (2016). Using dynamic sustainability indicators to assess environmental policy measures in Biosphere Reserves. Ecol- ogical Indicators, 67, 565-576.

https://doi.org/10.1016/j.ecolind.2016.03.021

[5] Brankov, J. (2010). Ekološki turizam u zaštićenim objektima prirode u Banatu. Beograd: Geografski institut „Jovan Cvijić“", Srpska akademija nauka i umetnosti.

[6] Buckley, R. (2003). Ecological indicators of tourist impacts in parks. Journal of Ecotourism, 2(1), 5466. https://doi.org/10.1080/14724040308668133

[7] Cottrell, S.P., Vaske, J.J., \& Roemer, J.M. (2013). Resident satisfaction with sustainable tourism: The case of Frankenwald Nature Park, Germany. Tourism Management Perspectives, 8, 42-48. https://doi.org/10.1016/j.tmp.2013.05.005

[8] Dolnicar, S., \& Grün, B. (2013). Validly measuring destination images in survey studies. Journal of Travel Research, 52(1), 3-14. https://doi.org/10.1177\%2F0047287512457267

[9] Dudley, N., MacKinnon, K., \& Stolton, S. (2014). The role of protected areas in supplying ten critical ecosystem services in drylands: a review. Biodiversity, 15(2-3), 178-184.

https://doi.org/10.1080/14888386.2014.928790

[10] Izveštaj o sprovođenju programa zaštite prirodnih dobara za 2019. godinu, (2020), Republika Srbija, Autonomna Pokrajina Vojvodine, Pokrajinski zavod za zaštitu prirode, Novi Sad.

[11] Kovačev, N., Romelić, J., Pivac, T., \& Lukić, T. (2014). Trips as primary and associated forms of other tourist Deliblato Sands movement. Researches Review of the Department of Geography, Tourism and Hotel Management, 43(2) 130-147.

[12] Kruger, M., Viljoen, A., \& Saayman, M. (2013). Who pays to view wildflowers in South Africa? Journal of Ecotourism, 12(3), 146-164. https://doi.org/10.1080/14724049.2013.871286

[13] Lee, T.H., \& Hsieh, H.P. (2016). Indicators of sustainable tourism: A case study from a Taiwan's wetland. Ecological Indicators, 67, 779-787. https://doi.org/10.1016/j.ecolind.2016.03.023

[14] Maple, L.C., Eagles, P.F.J., \& Rolfe, H. (2010). Birdwatchers' specialisation characteristics and national park tourism planning. Journal of Ecotourism, 9(3), 219-238. https://doi.org/10.1080/14724040903370213

[15] McCool, S.F., Moisey, R.N., \& Nickerson, N.P. (2001). What should tourism sustain? The disconnect with industry perceptions of useful indicators. Journal of Travel Research, 40, 124-131.

[16] Milićević, S., Bošković, N., \& Lakićević, M. (2021). Sustainable tourism development in mountain areas in Šumadija and Western Serbia. Journal of Mountain Science, 18, 735-748.

https://doi.org/10.1007/s11629-020-6239-4 
[17] Navarro, J.L.A., Martines, M.E.A., \& Jiménez, J.A.M. (2020). An approach to measuring sustainable tourism at the local level in Europe. Current Issues in Tourism, 23(4), 423-437. https://doi.org/10.1080/13683500.2019.1579174

[18] Pavlović, P., Kostić, N., Karadžić, B., \& Mitrović, M. (2017). The soils of Serbia. Springer. https://doi.org/10.1007/978-94-017-8660-7

[19] Plan upravljanja za SRP „Deliblatska peščara 2011-2020“, (2011). Petrovaradin: JP „Vojvodinašume"

[20] Pravilnik o unutrašnjem redu i čuvarskoj službi Specijalnog rezervata prirode „Deliblatska peščara“ („Službeni glasnik RS”, 10/2016).

[21] Program zaštite životne sredine Autonomne Pokrajine Vojvodine za period 2016-2025. godine, Sl. list AP Vojvodine, broj 10/2016.

[22] Puhakka, R., \& Siikamäki, P. (2012). Nature tourists' response to ecolabels in Oulanka PAN Park, Finland. Journal of Ecotourism, 11(1), 56-73. https://doi.org/10.1080/14724049.2011.647917

[23] Puzović, S., Panjković, B., Tucakov, M., Stojnić, N., Sabadoš, K., Stojanović, T., Vig, L., Marić, B., Tešić, O., Kiš, A., Galamboš, L., Pil, N., Kicošev, V., Stojšić, V., Timotić, D., Perić. R., Bošnjak, T., Delić., J., Dobretić, V., \& Stanišić. J. (2015). Upravljanje prirodnom baštinom u Vojvodini. Novi Sad: Republika Srbija, Autonomna Pokrajina Vojvodina, Pokrajinski sekretarijat za urbanizam, graditeljstvo i zaštitu životne sredine, Pokrajinski zavod za zaštitu prirode.

[24] Queiroz, R.E., Guerreiro, J., \& Ventura, M.A. (2014). Demand of the Tourists Visiting Protected Areas in Small Oceanic Islands: the Azores Case Study (Portugal). Environment, Development and Sustainability, 16(5), 1119-1135. https://doi.org/10.1007/s10668-014-9516-y

[25] Rasoolimanesh, S.M., \& Jaafar, M. (2016). Sustainable tourism development and residents' perceptions in World Heritage Site destinations. Asia Pacific Journal of Tourism Research, 22(1), 34-48. doi.org/10.1080/10941665.2016.1175491

[26] Scholtz, M., Kruger, M., \& Saayman, M. (2015). Determinants of visitor length of stay at three coastal national parks in South Africa. Journal of Ecotourism, 14(1), 21-47. https://doi.org/10.1080/14724049.2015.1023730

[27] Scholtz, M., Saayman, M., \& Kruger, M. (2012). The influence of the economic recession on visitors to the Kruger National Park. Journal of Economic and Financial Sciences, 5(1), 247-270. https://doi.org/10.4102/jef.v5i1.316
[28] Simić, D., \& Puzović, S. (2008). Ptice Srbije $i$ područja međunarodnog značaja. Beograd: Liga za ornitološku akciju Srbije.

[29] Sowinska-Świerkosz, B., \& Chmielewski, T.J. (2014). Comparative assessment of public opinion on the landscape quality of two biosphere reserves in Europe. Environmental Management, 54, 531-556. doi.org/10.1007/s00267-014-0316-9

[30] Štetić, S., \& Šimičević, D. (2015). Turistička geografija. Beograd: Visoka turistička škola strukovnih studija.

[31] Štetić, S., \& Trišić, I. (2020). Prirodni resursi za razvoj ekoturizma Specijalnog rezervata prirode „Obedska Bara“. Ecologica, 24(98), 224-231.

[32] Štetić, S., Trišić, I., \& Nedelcu, A. (2019). Natural potentials of significance for the sustainable tourism development - the focus on the special nature reserve. Journal of the Geographical Institute "Jovan Cvijić" SASA, 69(3), 279-287. https://doi.org/10.2298/IJGI1903279S

[33] Trišić, I. (2019). Opportunities for Sustainable Tourism Development and Nature Conservation in Special Nature Reserve "Deliblatska Peščara“. Hotel and Tourism Management, 7(1), 83-93. https://doi.org/10.5937/menhottur1901083T

[34] Trišić, I., Štetić, S., \& Maksin, M. (2020). The significance of protected natural areas for the tourism of the Vojvodina Province (Northern Serbia) - relevant factors analysis of the sustainable tourism development. Spatium, 43, 1-7. https://doi.org/10.2298/SPAT2043001T

[35] Twining-Ward, L., \& Butler, R. (2002). Implementing STD on a small island: development and use of sustainable tourism development indicators in Samoa. Journal of Sustainable Tourism, 10(5), 363-387. https://doi.org/10.1080/09669580208667174

[36] Vučetić, A. (2018). Importance of environmental indicators of sustainable development in the transitional selective tourism destination. International Journal of Tourism Research, 20(3), 317-325. https://doi.org/10.1002/jtr.2183

[37] Weaver, D. B. (2010). Geopolitical dimensions of sustainable tourism. Tourism Recreation Research, 35(1), 47-53. https://doi.org/10.1080/02508281.2010.11081618

[38] Zeljković, M. (2020). Attitudes of the local residents towards the possibilities of ecoturism development in the area of the Special Nature Reserve 'Deliblato Sands'. Collection of Papers - Faculty of Geography at the University of Belgarde, 68, 37-52. https://doi.org/10.5937/zrgfub2068037Z. 